Historic, archived document

Do not assume content reflects current scientific knowledge, policies, or practices. 



\section{PLANT STRAWBERRIES FOR BIGGER PROFITS}

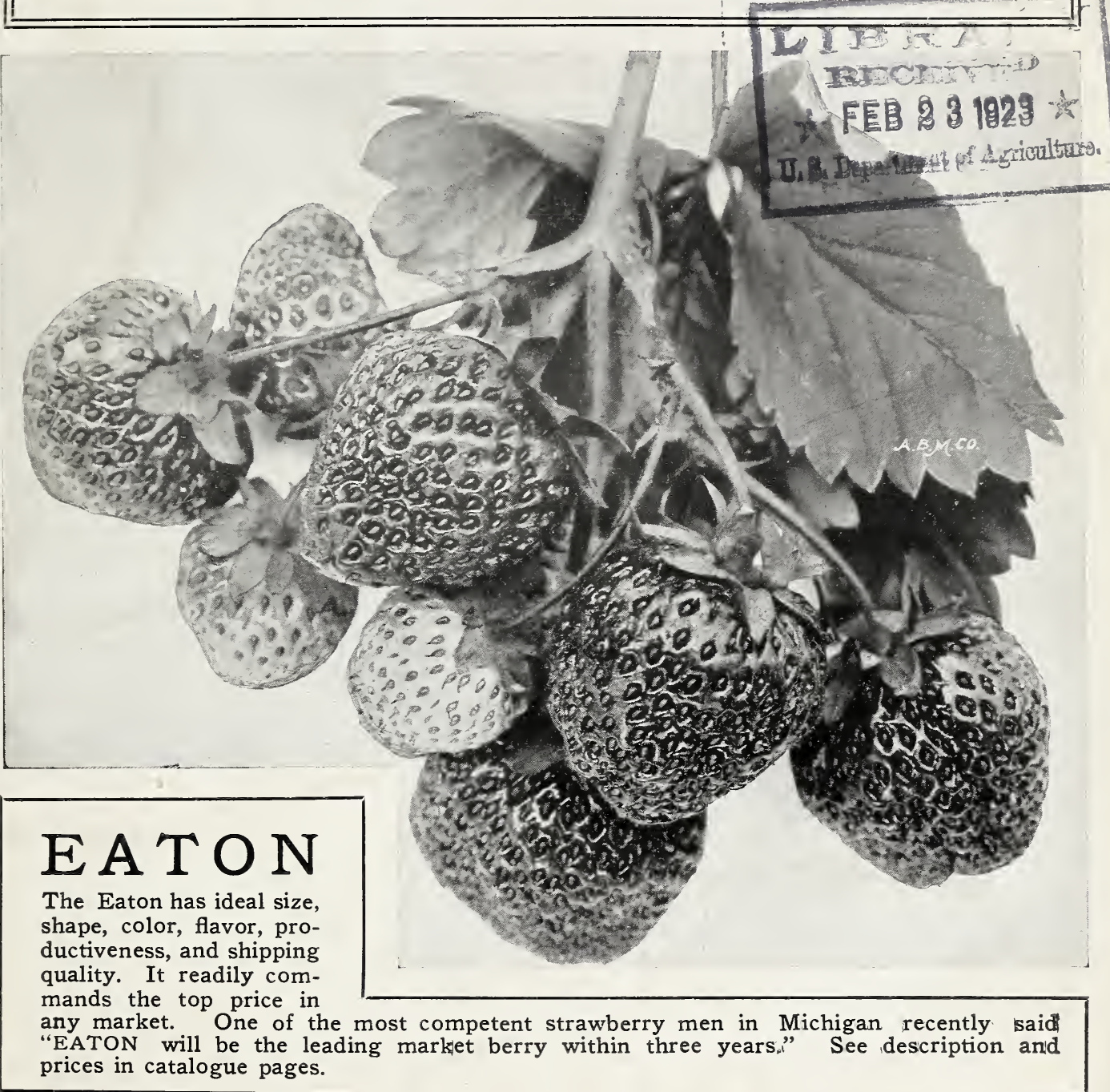

\section{Lake Shore Nursery Co.}

J. N. Williams, Proprietor

STRAWBERRY AND SMALL FRUIT PLANTS

Bridgman, Michigan 


\section{Instructions to Purchasers}

Express Shipments. When conditions are normal we would advise you to have all fair size shipments sent by express. The consolidation of the express companies under the head of the American Railway Express Co.. has eliminated much handling, and better service is given.

Freight Shipments. We advise you not to have any kind of plants shipped by freight, no matter what the distance may be, or the cost of transportation; it is not a safe nor reliable way to have live plants shipped. We assume no resposibility for loss or damage by freight shipment.

Parcels Post Shipments. Under the Parcels Post laws we are permitted to ship seventy pounds within the first three zones, and fifty pounds outside of the first three zones. We would recommend shipments of twenty pounds or under to go by parcels post, and shipments over twenty pounds by express.

Packing. We use slatted crates and plenty of damp moss in packing our strawberry plants. Strong boxes and barrels are used for the packing of other plants. Our plants are packed right, and they will reach you in good growing condition. We employ experienced packers and keep them under personal supervision.

Claims. Purchasers should inspect plants carefully upon arrival. If plants have been damaged by undue delay in transportation, or broken open, refuse to accept the shipment or pay charges. Place claim in your agent's hands immediately for the purchase price.

Substitution. We never substitute without instruction from the customer. We have unsurpassed facilities for storing and packing, and never dig plants in freezing weather.

Guarantee. Should any stock prove not true to name we will either refund the purchase money for same, or replace the stock with stock true to name; but are not liable for further damages, and while we are exercising great care to prevent mixtures, the above is to be a condition on which all stock is delivered.

References. Bridgman State Bank, Bridgman, Michigan; Postmaster, Bridgman, Michigan. In writing to above for references, please enclose postage for reply.

Order Early. Order as soon as you receive this catalog, for we have our full supply to draw from, while later on in the season it may become exhausted in some varieties. We mail acknowledgement of order on receipt of same. If you do not receive yours, write us.

Order Blanks. Order blanks are furnished for your convenience. Please use them, giving Postoffice, State and County. Advise date you wish shipment made, and whether you want it made by express or parcels post, or freight.

Shipping Season. The shipping season is April 1 to May 15.

Terms. Our terms of payment are cash with order. Remit by postal order or express money order, registered letter, or draft on Chicago or New York.

\section{CERTIFICATE OF NURSERY INSPECTION} No. 2651

This is to certify that I have examined the nursery stock of Lake Shore Nursery Co., of Bridgman, Michigan, and nind it apparently free from dangerous insects and dangerously contagious tree and plant diseases.

This certificate to be void after July 31, 1923.

Sept. 6, 1922.

W. R. HARTMAN,

Bureau of Foods and Standards, Michigan. 


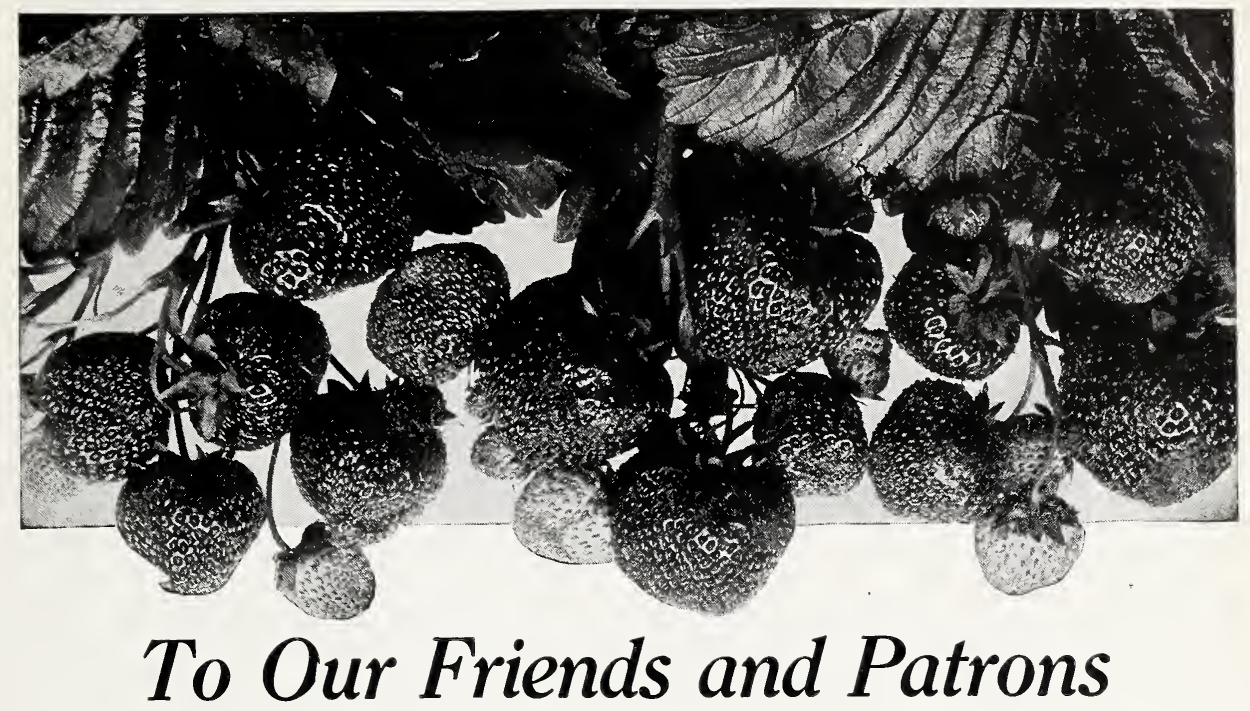

In dealing with our customers we have constantly endeavored to conduct our business upon the high, broad plane of square dealing and upright business methods. We have pursued the principle of furnishing the very best stock of small fruit plants at very reasonable prices, making every plant sent out a lively advertisement of upright methods, and by this policy have had the pleasure of a continual expansion of business.

We assure you that it will always be our aim to give you value received. The nursery business is a peculiar business, in that we are dealing in live plants; our business is concentrated into a few months' work, when everything should be done at once. Hence, we suggest that you let us have your order early; do not wait until planting time before making up your order. You can help us very materially if you will do this.

We do not feel that the transaction with our patrons terminates upon the delivery of the plants and the collection of the bill. It is our desire to continue to render them every possible service, in proper method of planting

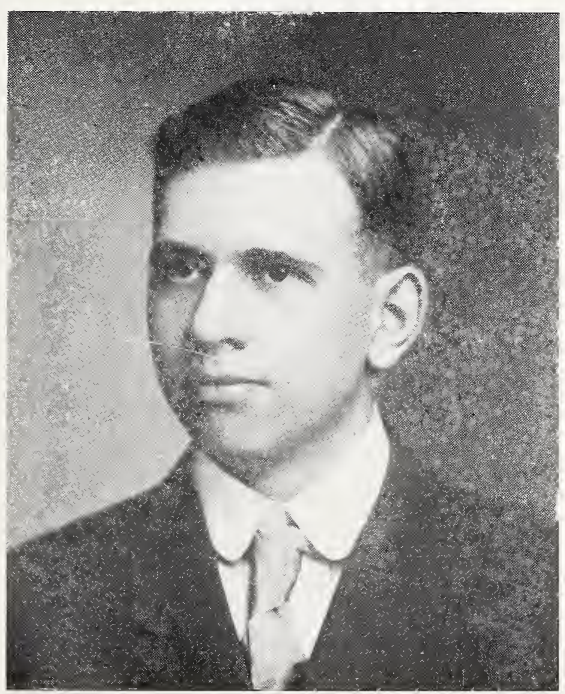

J. N. Williams. and caring for the plants, in order that they may realize the greatest possible returns from their investment.

The growing of small fruits requires less money to start, and also less land, and it brings larger returns for the effort expended. Small fruits are always in demand at a good profitable price, and their production is almost unlimited.

When buying plants the best is none too good for you, as it requires just as much time, labor and expense to grow a patch of common plants as it does to grow our heavy yielding varieties.

We wish to take this opportunity of thanking each and every one of our customers for their patronage, and hope to merit a continuance of the same.

Yours very truly,

LAKE SHORE NURSERY CO. 


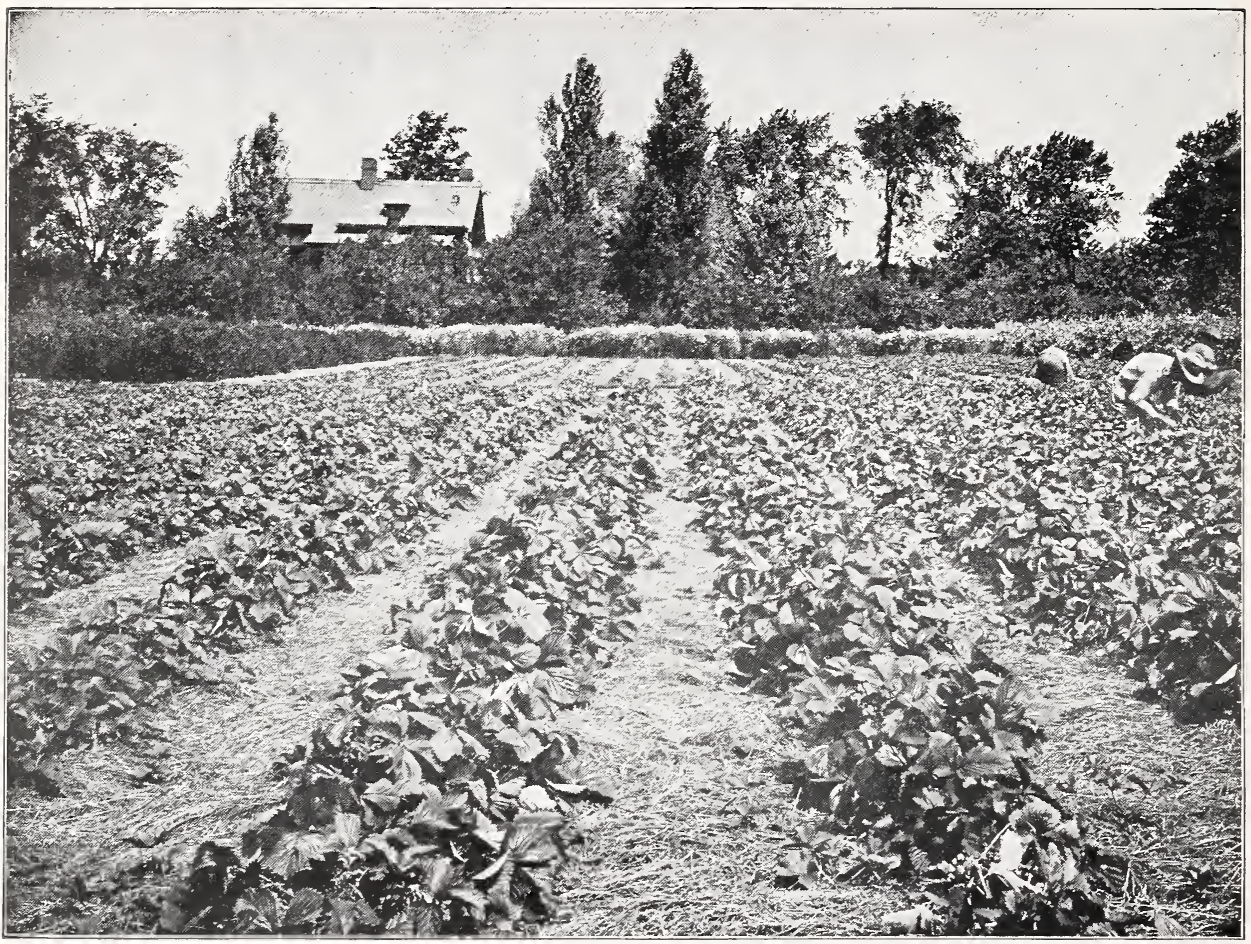

\section{Suggestions to Planters of Strawberries}

The soil and location best adapted to strawberry culture will vary somewhat in different sections. A sandy loam or a loam with a slight mixture of clay should, if properly handled, give the best results. One of the first requisites of the ripening fruit is moisture, hence a very dry or loose sandy soil is not recommended, although in moist seasons a fair crop might be harvested. Neither is a stiff clay adapted to strawberry growth, as it cannot be worked very early in the season without becoming cloddy, and later in the season is apt to bake.

Time of Planting. The time to plant varies with the climate. The earlier in the spring the better, because the plants are then given a chance to become established and better prepared to withstand dry weather.

Fertilizing. Stable manure, well rotted and generously used, is the best known kind of fertilizer for small fruits. A crop of clover, vetch, alfalfa, etc., plowed under, is also good.

Drainage. Tiling should be used to carry surplus water off the ground. Berry patches should be given the same attention in this respect as any other crop.

Care of Plants When Received. If your ground is not in condition or if the weather is unfavorable for planting, care for the plants as follows: Take each variety, a bunch at a time, cut strings and spread roots thinly along the side of a shallow trench, then cover the roots with dirt, not higher than the crown of the plant. If the ground is dry, sprinkle with water and keep moist until ready for planting. Plants can be kept in this manner for several weeks. If you can plant them in two or three days after arrival, they can be kept very nicely in a cool cellar without going to the trouble of heeling them in as mentioned above.

Preparation of Ground. Prepare the soil by plowing under well rotted stable manure, about twenty tons to the acre. It is impossible to get the ground too rich for strawberries. If stable manure is not available, clover or alfalfa sod land makes an ideal bed for strawberries, but should be well pulverized and worked up before planting. 


\section{Suggestions to Planters of Strawberries-Continued}

Marking can be accomplished by making an improvised marker out of four pieces of two by four and a piece of board 14 feet 8 inches long; spike a piece of two by four on the extreme end of the board, and then nail another piece of two by four, three feet eight inches from the first one, and so on across the board, thus making a sort of a sled. When finished, nail two poles on to act as shafts, which a man can easily draw, thus making four even rows across the field, three feet and eight inches between the rows.

Strawberries can be most conveniently planted by two persons; one making the holes and the other setting the plants. A common garden spade may be used for making the holes, which is done by giving the spade a slight backward and forward movement, being careful not to loosen the soil. The hole should be wide enough to easily receive the plant, and a little deeper than the plant requires. The roots should be straight down and slightly spread. This will give them more moisture and they will start right off. Be particularly careful to get the plants the proper depth; have the crown or bud of the plant even with the surface of the ground.

Cultivation. Cultivation should commence as soon as the plants are set. This helps to conserve the moisture, and in case of a heavy wind the plants will not be covered up with sand, as is the case many times with sandy land. Cultivate shallow and not too close to the plants, as this will disturb the new roots. We recommend cultivation at least once a week throughout the growing season.

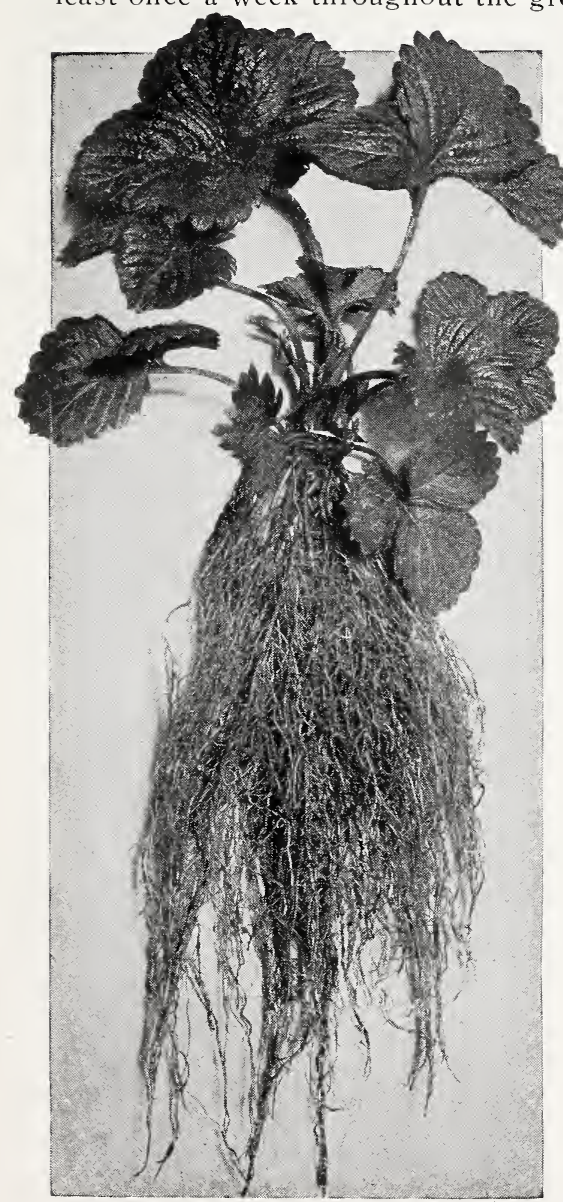

Removing Blossoms from New Plants. Strawberries should not be allowed to blossom the first year planted. The blossoms should be cut off as fast as they appear the first season. We find an old discarded pair of scissors to be just the thing. Removing the blossoms allows the plants to use their vitality building up a better root system preparatory to producing a large crop of fruit the following season.

Mulching. When the ground commences to freeze in the fall, it is necessary to mulch the strawberry beds, if the ground is of a nature that is liable to heave during freezing and thawing weather. Marsh hay or straw proves to be the best mulch; apply it lightly over the entire row. As soon as growth starts in the spring, this mulch should be removed from the plants. It can be left between the rows if desired. This will hold moisture and keep the weeds down.

Care of Patch After First Year. Some of our customers may want to pick their strawberry beds the second and possibly the third year. In case you do, after the picking is over, mow your strawberry bed, rake and burn the weeds, thus preventing the weeds seeding. As early in the spring as possible throw a back furrow between the rows with a one-horse plow, leaving a row about 12 inches wide. Cultivate this down level again, pull out the weeds in the row and burn. With this treatment patches have been picked four and five seasons.

Perfect and Imperfect Varieties. Those varieties of strawberries marked (Per.) are perfect flowering and need no other varieties to pollenize them. Varieties marked (Imp.) must be planted with one of the perfect varieties for fertilization. Not more than four rows of the imperfect varieties should be set together, otherwise the pollen from the perfect plants will not properly fertilize Strawberry Plants as We Grow Them. them. 


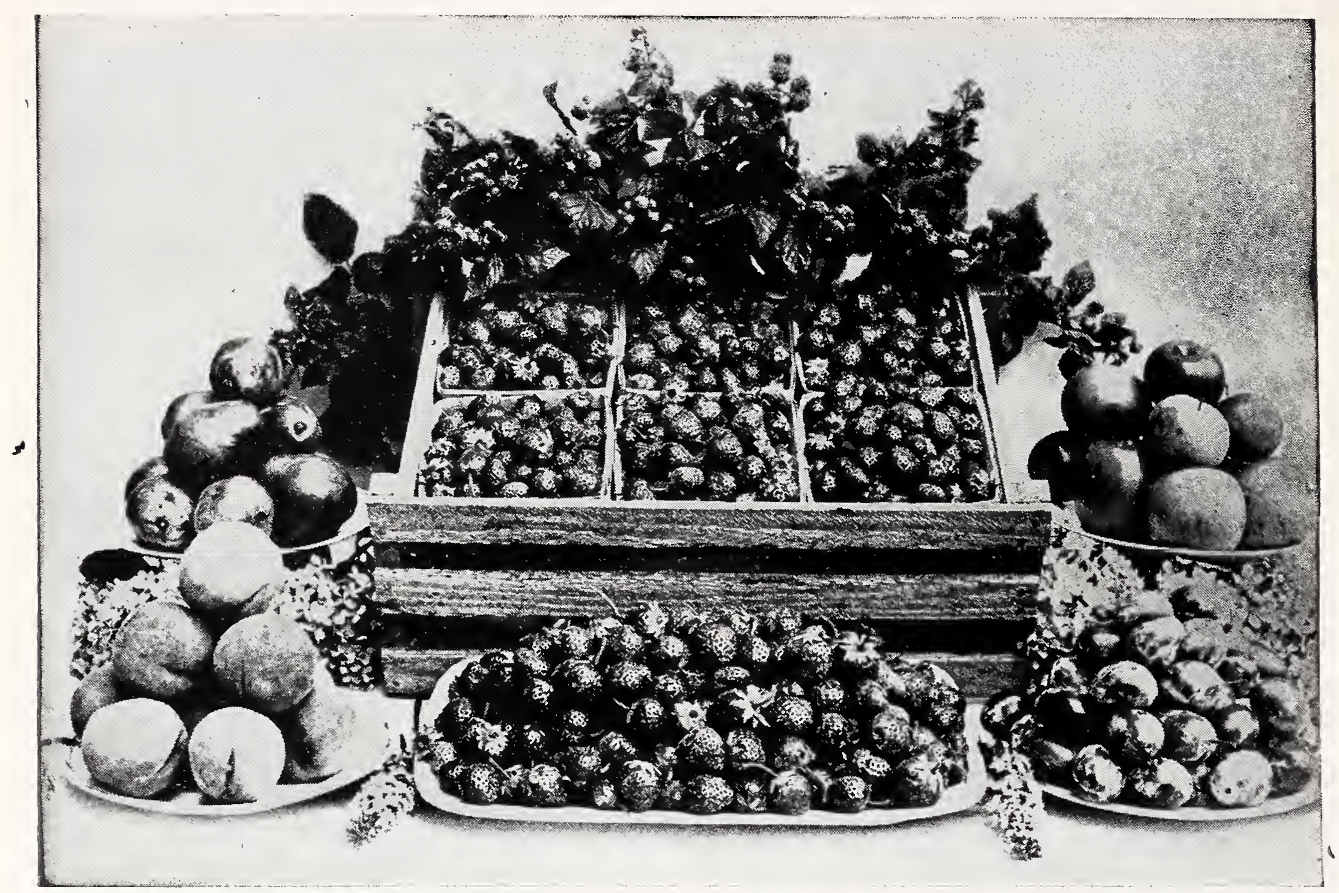

\section{Everbearing Strawberries}

\section{Progressive (Per.)}

This wonderful everbearing strawberry is so well known to the public that it hardly seems necessary to go into detail.

By planting Progressives you will have a continuous supply of strawberries from July till the killing frosts come. The continued productiveness of this strawberry is simply amazing. It bears heavily of a rich, dark red color berry, with a flavor distinctly its own, holding its size well toward the end of the picking season.

It is really a pleasure to grow such strawberries as these. We do not hesitate to recommend them to anyone desiring to raise strawberries and lots of them. It is needless to cut the blossoms from the Progressive Everbearing; they are so full of life that the original plants set in April or May will often have more than one hundred berries to the plant at one time. A little money invested in Progressives this year will bring you large returns. These berries often bring as high as one dollar a quart, bearing as they do long after other berries are gone.

\section{Champion (Per.)}

Close observation shows the Champion to be similar in many respects to the Progressive. It bears heavily and is a good drought resister.

We quote Mr. Edward L. Lubke, the introducer, for a description of its qualities and merits.

"The Champion is a better drought resister than any other known variety, continuing to bear heavily through drought period. As many as 256 berries have been found on one single plant."

Dear Sirs:- I received my plants April 4. They were fine. Don't forget to send me your catalog next year, as I gave mine away to a party that wanted to get some berry plants from you. I have had a great many strawberry beds, but no plants as fine as yours. These are the first raspberry plants that I have ever had of my own, so had some one else set them. Enclosed find money for the parcel post charges on plants. E. WAGNER, Illinois. 


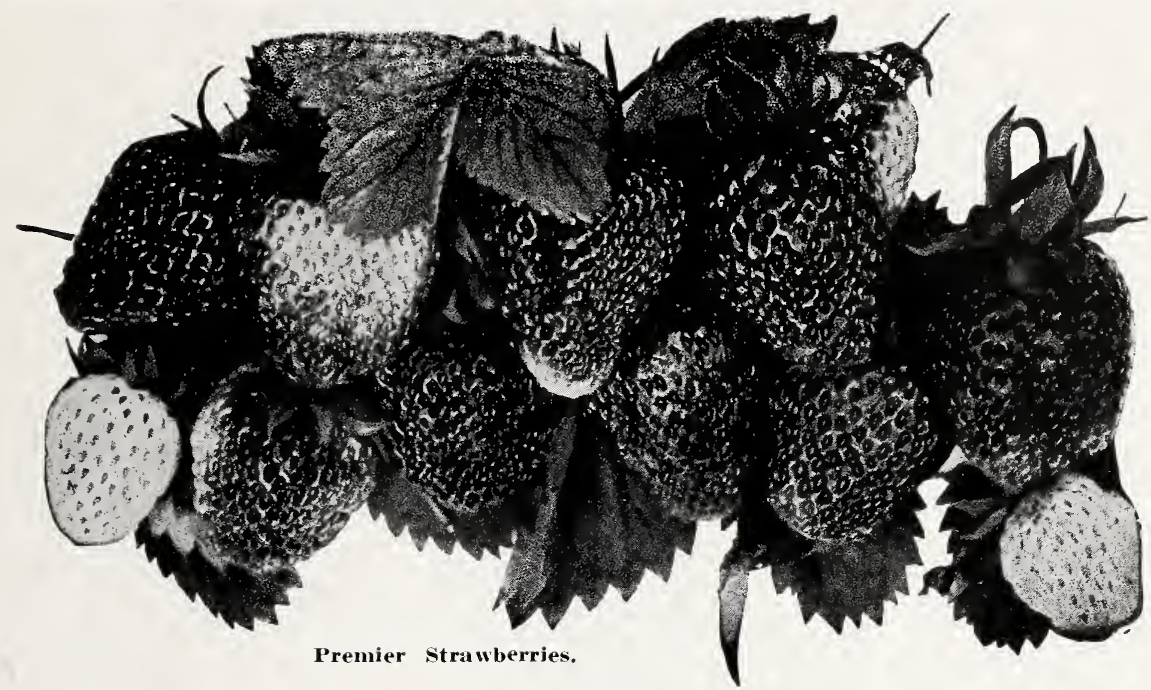

\section{Big Profits in Early Strawberries}

\section{Charles I}

This is one of the very earliest of strawberries. Fruit is large, good quality and color. It is a heavy plant maker, deep rooted, making it an excellent drought resister, and it will do well under the most trying conditions.

\section{Premier}

By its true merits the Premier is swiftly coming to the front. It has the qualities necessary to make it one of the foremost money-makers-that is, earliness and productiveness. It ripens nearly a week sooner than any of the earlier varieties. The fruit is firm, bright red, extra large with a fine flavor. The Premier is a strong pollenizer, vigorous grower and a heavy producer over a long season. Although it is a comparatively new variety, in our opinion, you can not make a mistake by planting heavily to them. Include some of these fine plants in your order.

\section{Cooper}

A large early berry of exceptionally high quality and color. Noted particularly for its immense size. This berry is destined to become a great favorite among strawberry growers. Cooper plants have been on the market for only two or three years, and we are not going to be able to fill all the orders asking for this variety. It's going to be a case of "first come first served" this year.

25 Howard 17-Early.

25 Gibson-Medium Late.

\section{COLLECTION NO. 1}

25 Senator Dunlap-Medium Early. $\} \$ \$ 1.00$

Postpaid.

\section{COLLFCTION NO. 2}

In offering this collection we have endeavored to include a variety of all Small Fruits for the modern garden:

200 Strawberry Plants.

12 Cumberland Black Raspberry Plants.

12 Early King Red Raspberry Plants.

12 Eldorado Blackberry Plants.

6 Concord Grape Plants.

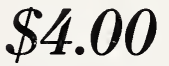

Not Postpaid 


\section{Midseason and Late Varieties}

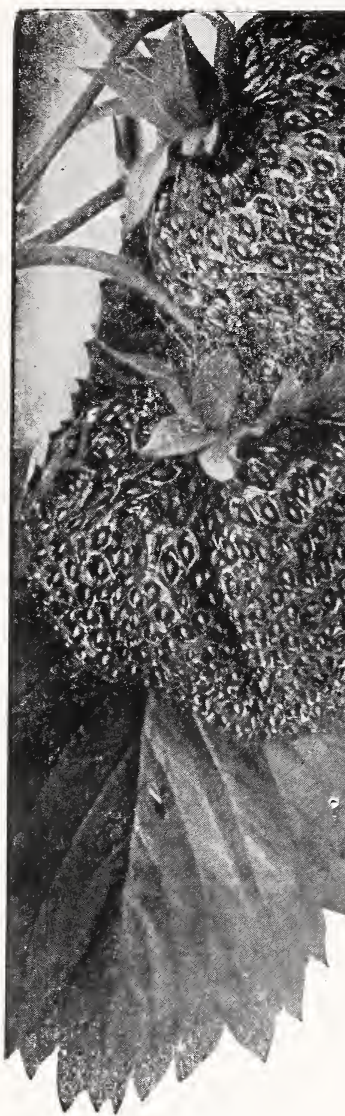

Gibson.

\section{Gibson (Per.)}

It has been but a comparatively short time since the Gibson first made its appearance in the strawberry fields. It has made remarkable progress toward attaining its leadership of the strawberry kingdom. By giving a brief analysis of the Gibson, it can be readily seen how it has made such remarkable progress. The plant is of a hardy nature, heavy root system, and drought resisting; will respond quickly to good care on any rich soil. The bud of the Gibson is large and hardy, maturing three, and sometimes four long and stocky fruit stems. The foliage is produced in abundance, thereby protecting the great loads of berries from the direct rays of the sun. The fruit is immense -unsurpassed in quality, appearance and flavor, and will command a high price on any market. It is an excellent canning variety with but few real competitors.

\section{Stevens Late (Per.)}

This variety is a good late variety, beginning to pick shortly after the second earliest. It is practically immune from frosts.

The Stevens Late makes a strong vigorous growth, is a heavy plant maker, and matures a short stem. The berry is irregular in shape and uniform in size, color bright red, flesh firm and protected by prominent seeds. This variety is late in ripening and will prove a money maker for those who want a late berry.

\section{Aroma (Per.)}

This old time and well known variety seems to be gaining in popularity. It is a great favorite with the Southern growers. Although the Aroma will do well on any good soil it is more adapted to the heavier soils. Berries are produced in immense quantities, fruit is large, regular, and uniform--fancy looking and the quality and market value is the very highest. You cannot go wrong in planting the Aroma this season.

\section{Brandywine (Per.)}

The Brandywine is a late variety. The berry has wonderful flavor, bright red, and regular shaped, rather large, holding shape well toward the end of the season. Don't fail to include some Brandywine with your order.

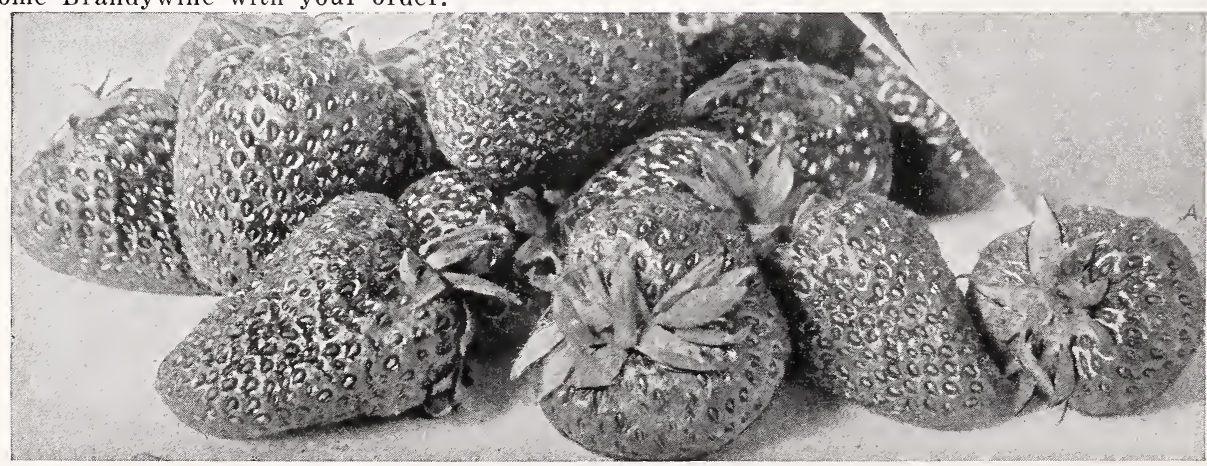

Brandywine Strawberries. 


\section{MIDSEASON AND LATE VARIETIES-Continued.}

\section{Eaton (Per.)}

Today this strawberry ranks among the very best all around strawberries obtainable. We recommend it very highly to everyone wanting an extra fine strawberry, of absolute dependability. Conical in shape, rich red in color, firm in texture, it is rapidly gaining the favor of the big shippers of strawberries. Don't fail to order plenty of these excellent strawberry plants.

\section{Dunlap (Per.)}

If you are in doubt as to the variety of strawberry to plant for a money crop, plant Dunlap. You cannot fail; it will thrive under the most trying conditions. If vegetation exists, Dunlap will grow. The Dunlap is very prolific both in plant and fruit production; the individual plant is small, but very hardy in bud and roots, making it a good drought resister and giving assurance of a generous supply of the most luscious dark red fruit you ever ate. It is such a great plant maker that to outain the highest quality fruit the runners should be cut off after the row has attained a width of from eight to twelve inches. The fruit is of a rich dark red color, rather conical in shape, and is rather firm. These qualities suggest to you a No. 1 market berry, which it is; as a canner, it has few, if any, competitors. Play safety first and include Dunlap in your order this spring.

\section{Dr. Burrill (Per.)}

The Dr. Burrill is fast gaining popularity in the strawberry fields of the country, with the demand steadily increasing. In general appearance it resembles the Dunlap, its firm nature making it a splendid shipper, one of the best canners, and makes a fine table dessert. The Dr. Burrill is a very heavy plant maker; will grow in almost all localities. We have a limited quantity of genuine, high quality Dr. Burrill plants. Dr. Burrill should be included in your order.

\section{Howard 17}

This berry has been in the background for the past few years, but is rapidly gaining in favor. It is claimed by many growers, after testing out Howard 17, that it is almost exactly like the Premier and that they are the same berry. Our observations are that the Howard is later in ripening than the Premier, and the fruit is of a darker color. It has an unusually strong and vigorous root system, large bud, and very large fruit. The large bright scarlet fruit makes a very attractive package and brings a good price on any market. It will pay you well to plant heavily to the Howard 17.

\section{Kellogg's Prize (Late. Imp.)}

We have been able to see Kellogg's Prize in the fruiting season. The Kellogg's Prize being pistillate, we would suggest fertilizing it with Aroma. Kellogg's Prize is very prolific of very large, glossy, dark red, regular shaped berries.

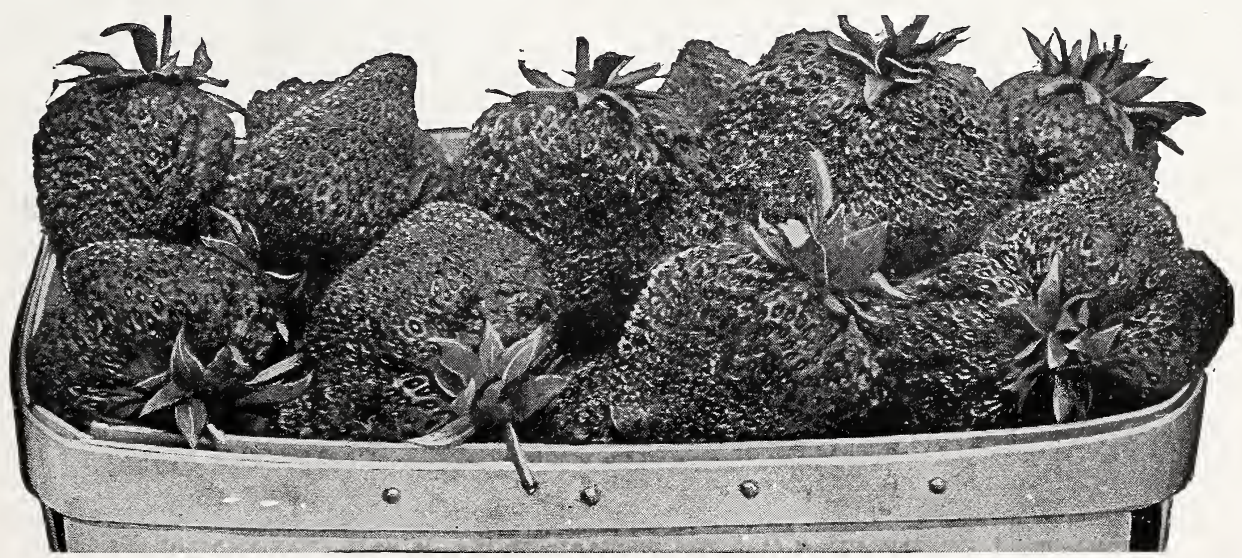




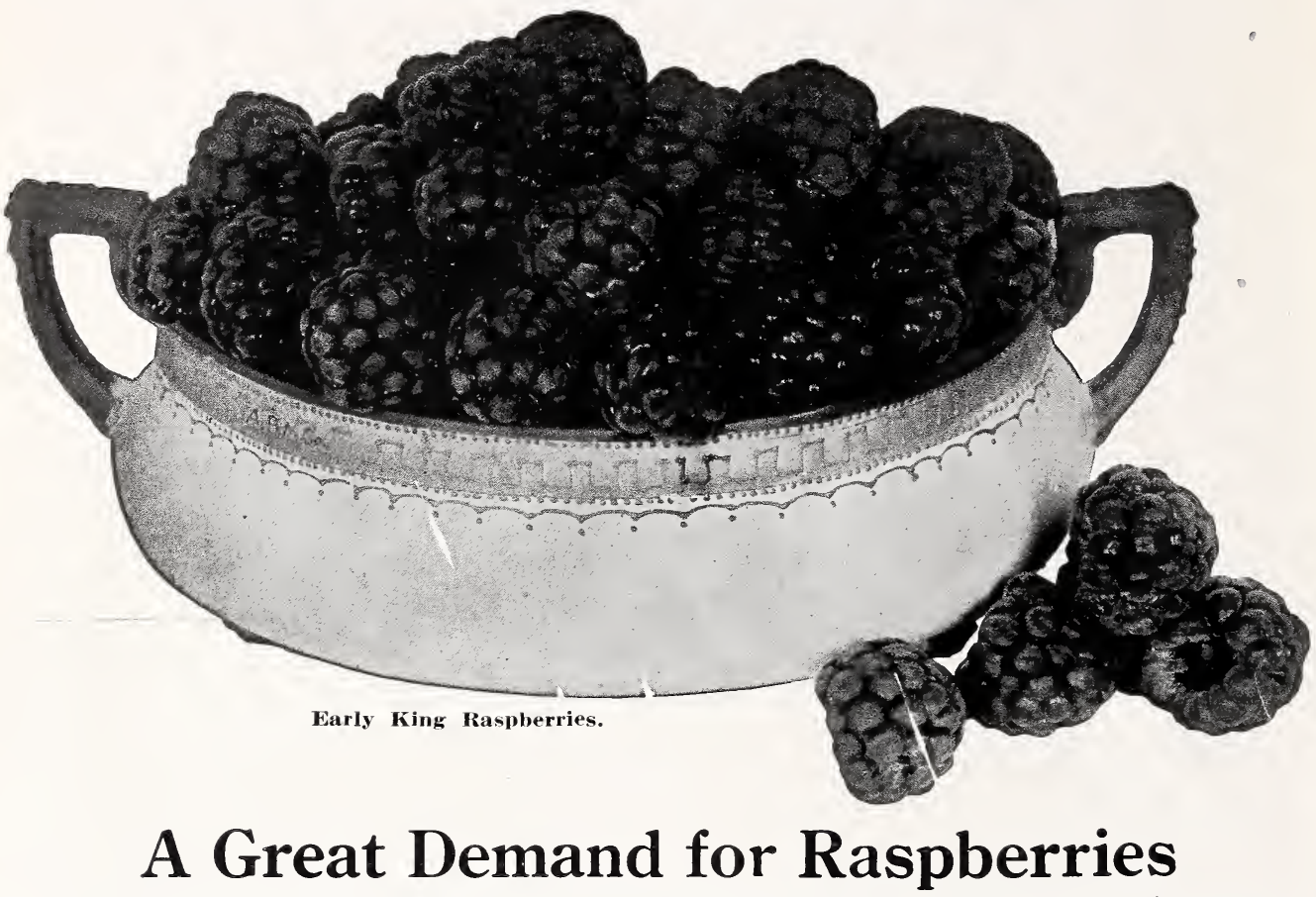

Red Raspberries grow' on any soil that would be suitable for a common crop such as corn or potatoes. It is a very delicious fruit and is in great demand everywhere. They should be planted three and one-half feet apart in the row and six feet between the rows. This would require 2,100 plants to the acre. Planting should be done as early in the spring as possible. Keep the raspberries in hills as much as possible, leaving not more than six good canes to the hill. All young shoots appearing between the hills and between rows should be cut off as fast as they appear. Cut out the old wood as soon as the crop is harvested, remove from the field and burn.

\section{Early King}

Nearly all of the red raspberries grown in this section are King. It is the most profitable and popular red raspberry grown. With good marketing facilities for fancy and early raspberries, we believe you can make money faster with a patch of King raspberries than with any other variety of fruit. The berries are large, firm, and bright red, easy to pick, and bring top prices. We guarantee satisfaction with Early King. Include some of these popular plants with your order this spring, without fail.

\section{St. Regis}

This new Everbearing variety gains in popularity each year. Fruit begins to ripen very early and continues until October. Berries are bright red, sweet, and large. Its firmness makes it a good shipper. St. Regis is a very heavy bearer in the regular raspberry season and in addition continues bearing all summer and late in the fall.

\section{Purple Raspberries}

\section{Columbian}

This is a raspberry of unusual sweetness, suitable for table use and canning. It is grown in large quantities in many sections, and there is always a demand for these raspberries at high prices. While we do not recommend the Columbian for commercial purposes, every family should grow enough of them for home use. Send us your order now.

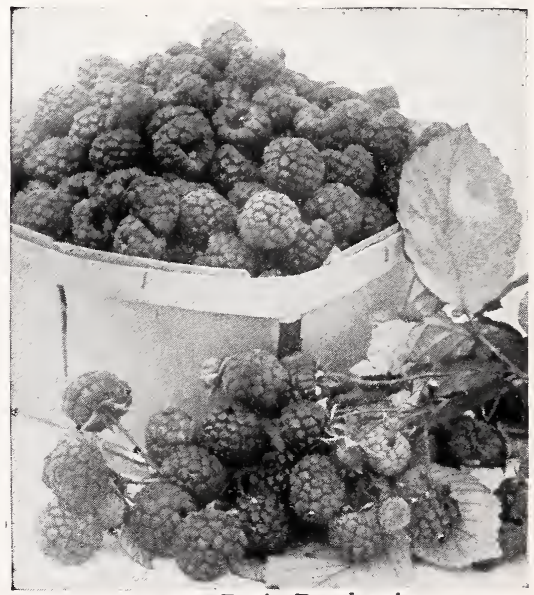

St. Regis Raspberries. 


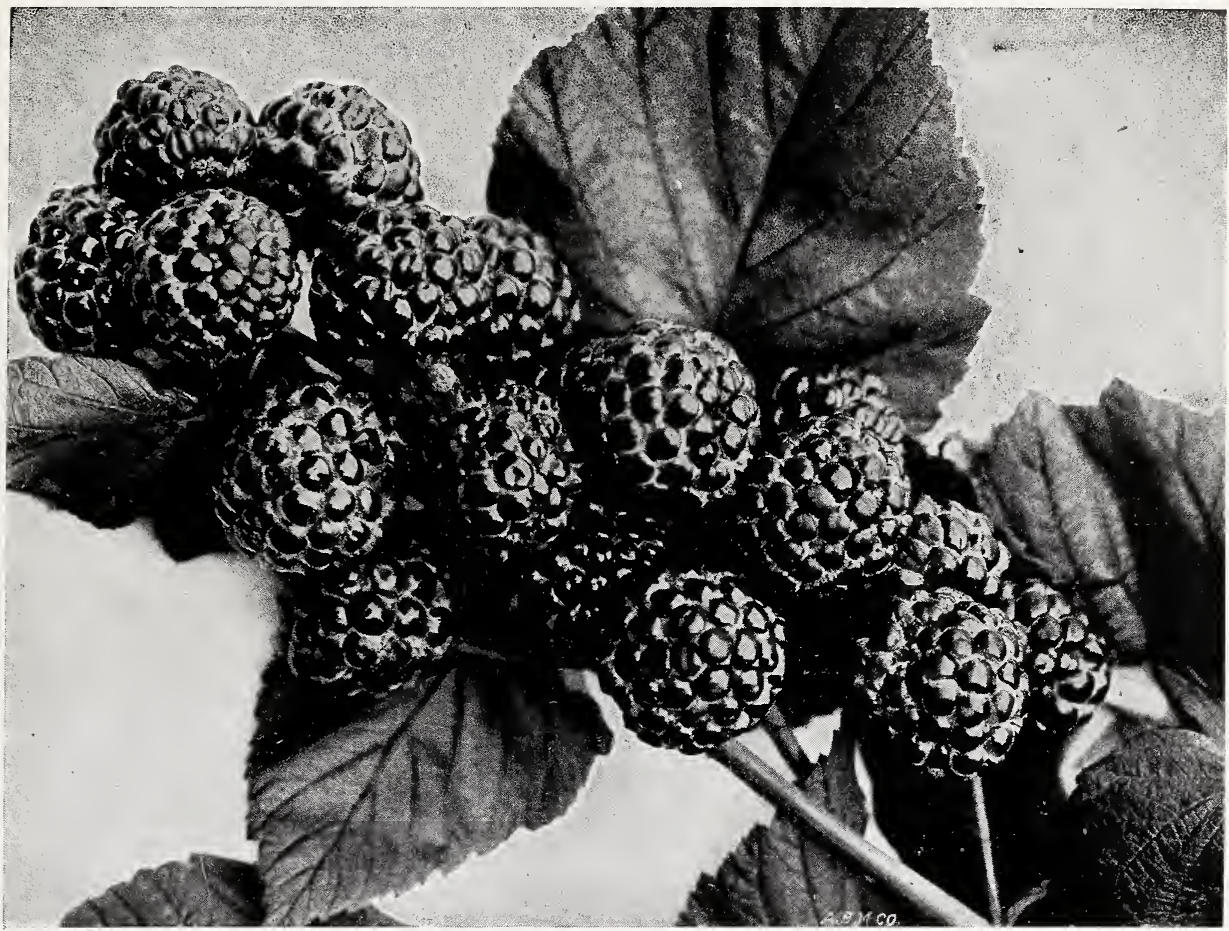

Cumberland Raspberries.

\section{Black Raspberries Bring Big Profits}

For the most profitable results Black Raspberries should be planted early in the spring. For the best field culture they should be planted $3 \frac{1}{2}$ feet apart in rows, with the rows 7 feet apart, requiring about 1725 plants to the acre. When the young cane has attained a height of 18 to 20 inches the tops should be pinched off, using a common pocket knife. This causes the cane to throw out laterals, forming the bush. After the fruit has been picked cut out all the old canes to allow plenty of room for the new ones to develop. In the spring both young and old patches should be trimmed leaving the laterals about 6 inches long, the bush then being about 30 inches high. This is all the trimming necessary. Cultivate very often.

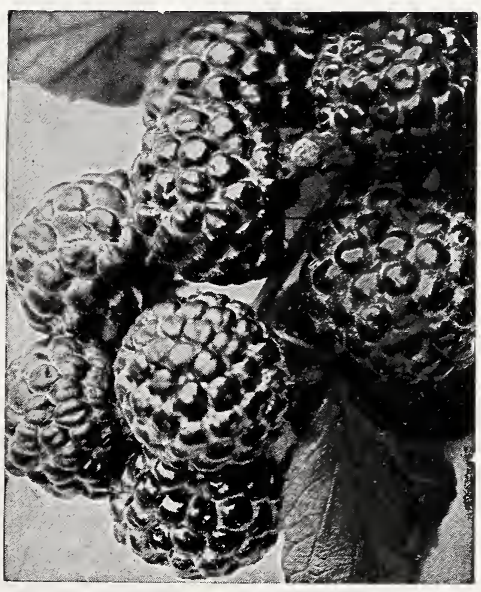

Plum Farmer Raspberries.

There is nothing nicer or more delicious than a fresh dish of Black Caps. Order Black Raspiberries row.

\section{Cumberland}

The most productive and biggest black raspberry grown. The Cumberland is very hardy, having withstood temperature as low as 12 to 14 degrees below zero, without injury. It has no disease of cane or foliage and grows berries not approached for size, quality or appearance by any variety. Cumberland ripens medium early and continues through the raspberry season. This variety is far ahead of all other lack raspberries in existence, the standard of quality. It will bring you big returns on your investment.

\section{Plum Farmer}

Plum Farmer is the early black raspberry variety. It is a good grower, thrifty, with clean, bright foliage. The fruit is firm, large, and thick nieated, sells for high prices as it is one of the first on the market, ripening a week or ten days before other varieties. 


\section{Grapes}

Any naturally high soil with good air circulation is best adapted for grape culture, although any well drained soil will grow them. For field culture plant twelve feet apart in the row and nine feet between rows, requiring 450 plants per acre. There is very little labor attached to raising grapes. Pruning is most essential. It must be done in the late fall or early spring before sap begins to rise.

Grape vines will grow and do well anywhere, rock, sand, clay, any soil that is not too wet.

Cultivate well the first year. The second year set posts and wire as follows: Posts should be set 16 to 20 feet apart, using 8 foot posts. Set $2 \frac{1}{2}$ or 3 feet in the ground. A bottom wire should then be placed $3 \frac{1 / 2}{2}$ feet from the ground and the top wire $1 \frac{1 / 2}{2}$ feet above the bottom wire. This will admit of plenty of air circulation when the foliage is heavy. Train best vine upon a string tied at bottom of stock leading to top wire. Four vines should be trained, two on the top wire and two on the bottom wire. These vines should have 15 buds on each of the four vines. Keep all growth cut off under bottom wire.

CONCORD. The most popular grape in America. Head and shoulders over all the other varieties. Bunch large, compact, covered with big tender skin berries, but sufficiently firm to carry well to distant markets. Concord is by far the best and most profitable market grape grown.

MOORES EARLY. Is decidedly the best early grape grown. Ripens from two to four weeks earlier than the Concord. Berries, dark blue, sweet and juicy; bunches as a rule are large and compact. Always sells at a premium over all other earlies.

\section{Dewberries}

LUCRETIA. Undoubtedly the leading and most popular of this variety. Thriving anywhere, winter protection should be furnished them in the northern states where winters are sometimes rather severe. Vines are very hardy, very prolific. Plant in rows 5 feet between rows, 3 feet in the rows; propagation from tips. Because of their trailing habit, we recommend using either stakes or posts and wire; if stakes are used, a stake $3 \frac{1}{2}$ feet long is required at each plant; if posts and wire are used, posts 3 feet above the ground, a wire run along on top of the posts is required. In the spring select thrifty, hardy vines, cut the rest of the vines away, tie these to the wire or stakes, cut the tips of the vine off, this insures a better quality of fruit. Fruit is of better qualiy than Blackberries, of a jet black color, oblong, large, sweet and juicy, very attractive, a quick seller on the market.

\section{Blackberries}

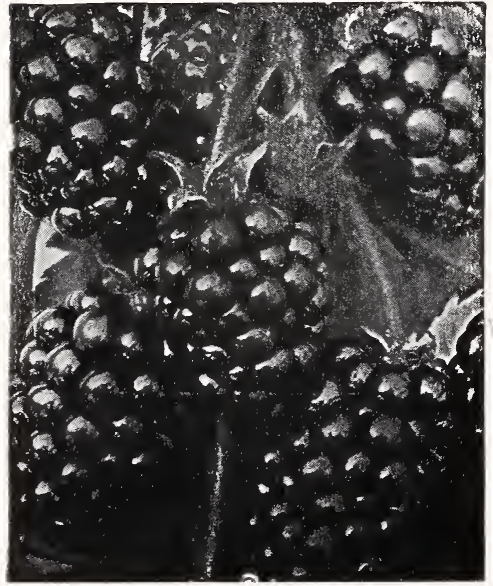

Eldorado Blackberries.
For best field culture the blackberry should be planted 4 feet apart in the rows with the rows 7 feet apart. This allows for 1,800 plants to the acre. Blackberries are grown without a great deal of trouble. When the plants are $2^{1 / 2}$ or 3 feet high pinch out the centers, giving the plants strength in keeping up. In order to obtain best results you should be careful not to leave too much wood. Blackberries make fine wines and cordials as well as excellent pies.

Give blackberries a good, strong soil, full of humus, prune and cultivate them properly, and you are sure to be pleased with the results.

ELDORADO. The Eldorado is unquestionably the best blackberry plant known, and is unexcelled or unequalled both as a commercial variety and for the home garden. It thrives in the very cold regions without winter protection; is a strong, upright grower, forming sturdy canes. The berries are large and firm, making them excellent shippers. The color is jet black, and the flavor is excellent, having a rich aroma; melting and juicy. Eldorado is highly recommended by experiment stations and growers everywhere, and you can depend on a big crop of luscious, sweet blackberries if you plant this variety. Let us have your order. 
Order No.

Date Rec'd

Amount, \$

Do Not Write in This space.

Amt. Enclosed
Lake Shore Nursery Co.

Bridgman, Michigan

PLEASE SEND PLANTS NAMED BELOW TO:

Name

Rural Route No.

Post Office

Express Co.

County

Ship by

Ship About

How to ship

State

When to ship

Express Office

Shall We Substitute Some Other Variety if Out of the Kind Ordered?

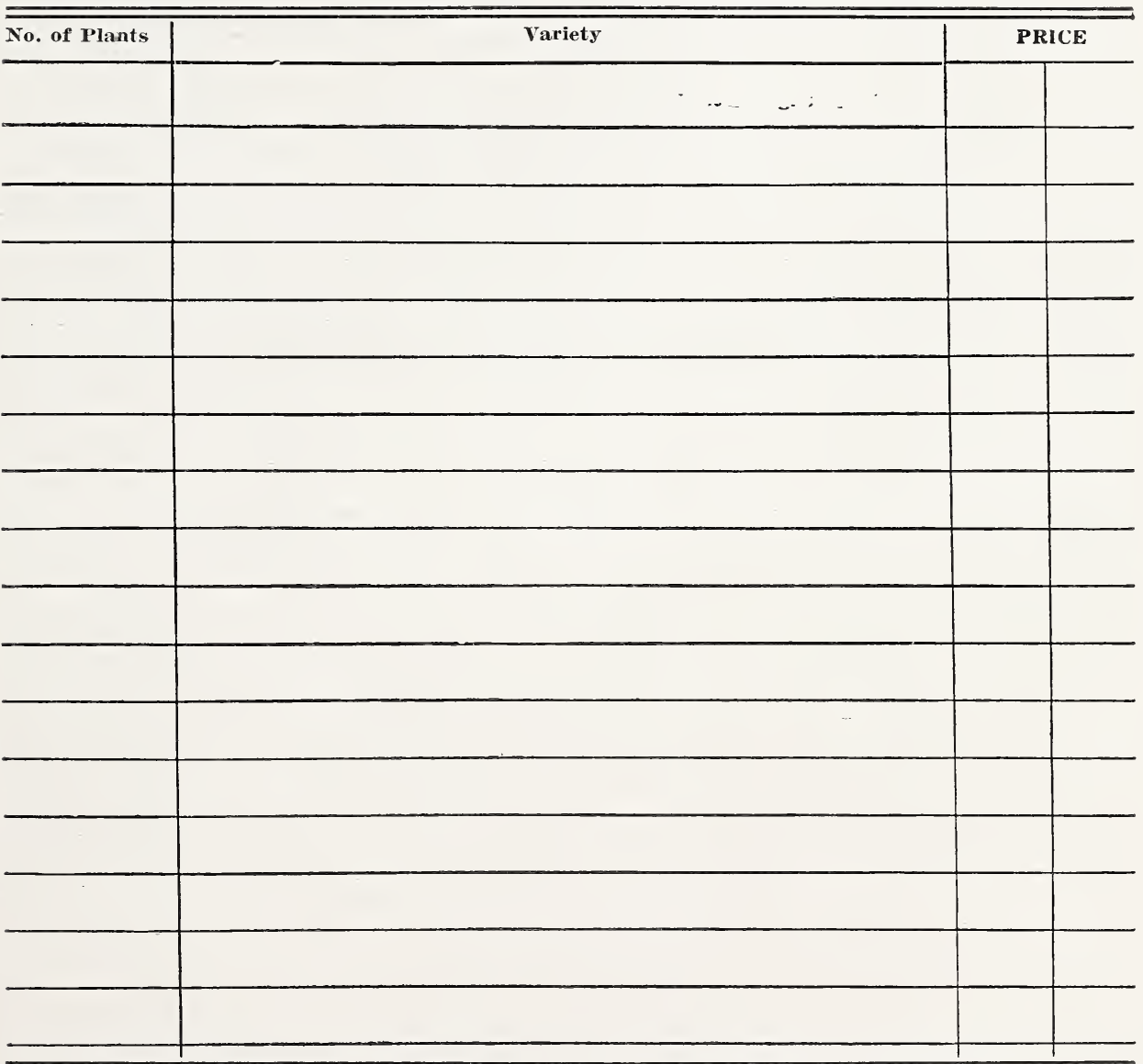


ORDER SHEET-Continued.

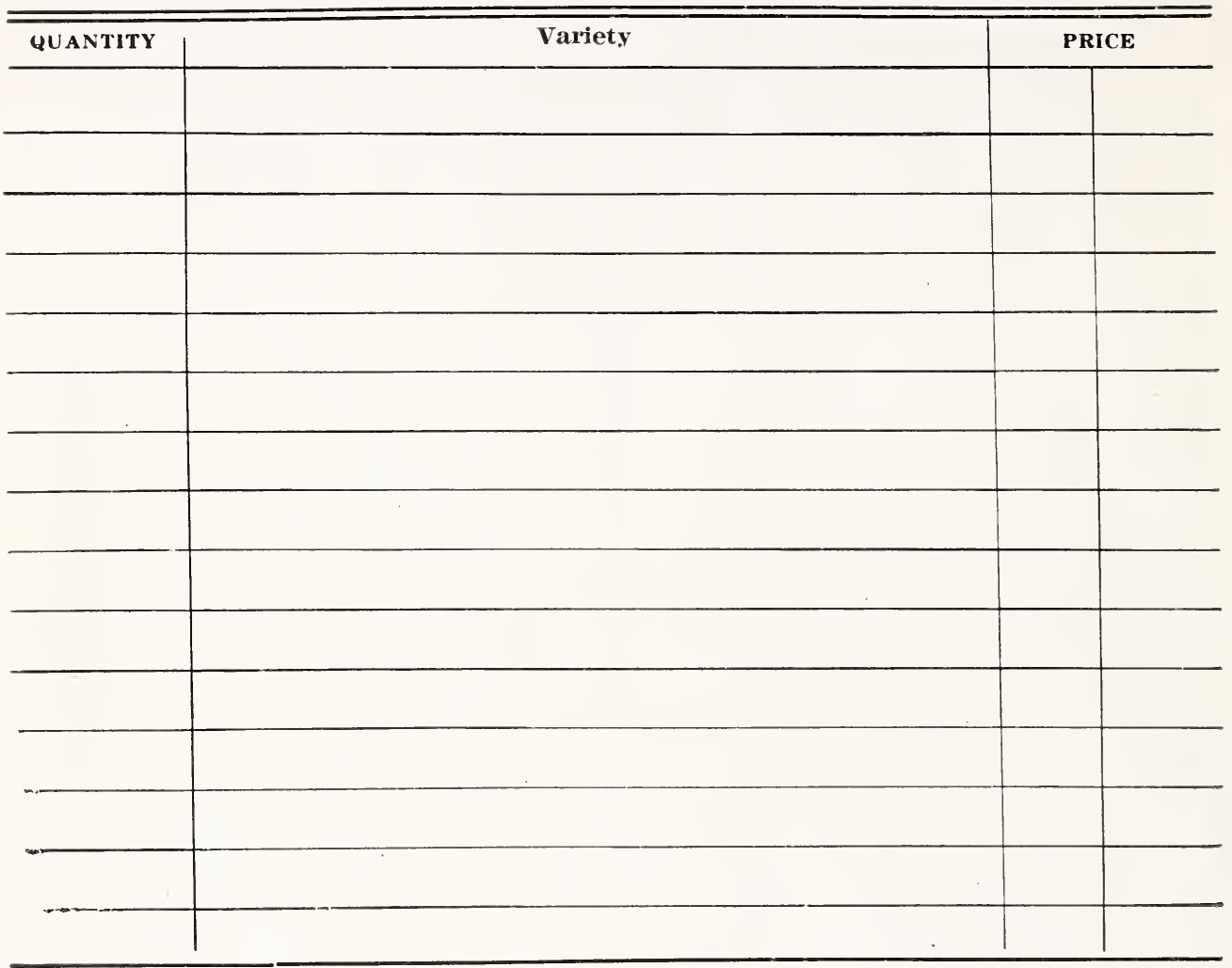

If you know of berry growers who would appreciate our catalog, and will write their addresses below, we will be glad to send you a few extra plants. 


\section{Price List}

S'TRI WIBERRIES

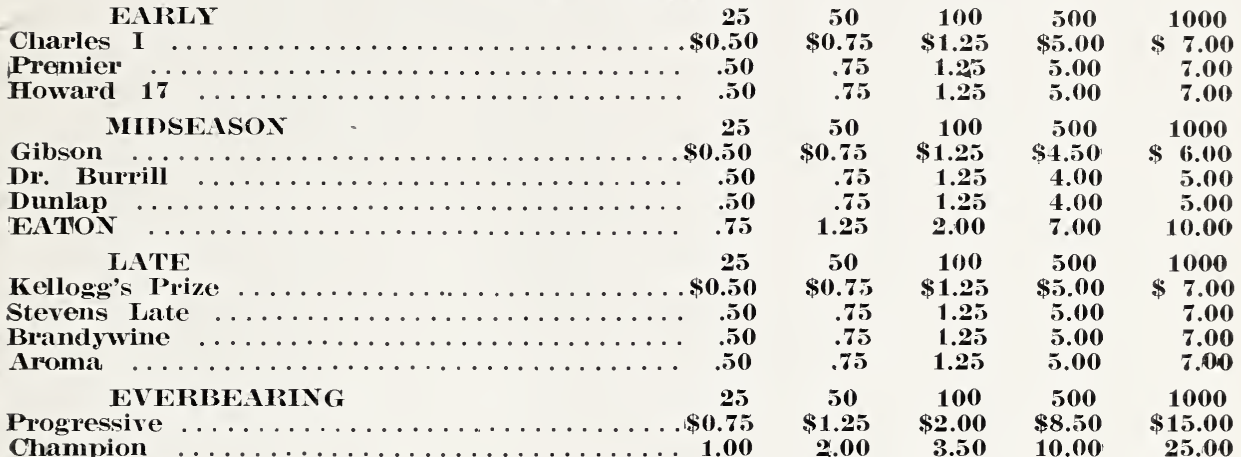

RED R.ISPBERRIES

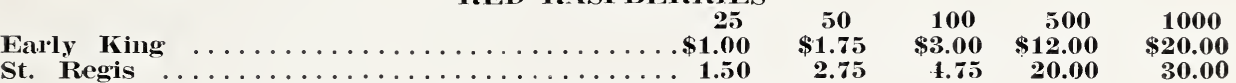

BLACK RASIBERRIES

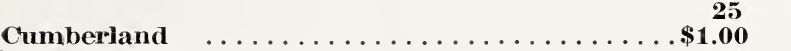

Plum Farmer . . . . . . . . . . . . . . 1.00

$50 \quad 100$

$\$ 1.75$

1.75

$\$ 3.00$

3.00

Columbian (Purple)

1.50

2.75

4.75

500

$\$ 12.00$

12.00

$\mathbf{2 0 . 0 0}$

1000

$\$ 18.00$

18.00

35.00

\section{BLACKBERRIES AND DEWBERRIES}

Eldorado $\ldots \ldots \ldots \ldots \ldots \ldots \ldots \ldots \ldots \ldots \ldots \ldots \ldots \ldots$

50

100

$\mathbf{5 0 0}$

1000

Lucretia (Dewberry)

1.50

2.75

4.75
4.75

$\$ 20.00$

$\mathbf{2 0 . 0 0}$

$\$ 35.00$

35.00

Each

Concord, 1-yr. large .....\$0.20

Concord, 1-yr, medium ..... .20

Moore's Early, 1-yr. medium .20

\begin{tabular}{cc}
\multicolumn{2}{c}{ GRA PES } \\
6 & 12 \\
$\$ 1.00$ & $\$ 1.50$ \\
1.00 & 1.50 \\
1.00 & 1.50
\end{tabular}

APPLES

Price, all varieties:

50
$\$ 4.50$
4.50
4.50

100

$\$ 8.00$ 7.00 8.00

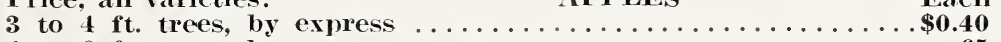

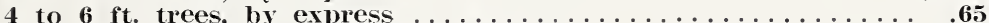

2 to 3 ft. trees, parcel post, prepaid

Price, all varieties:

PEARS

Eacl:

3 to 4 ft. trees, by express $\ldots \ldots \ldots \ldots \ldots \ldots \ldots \ldots \ldots \ldots \ldots \ldots \ldots \ldots$

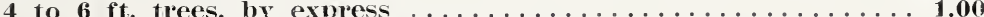

2 to 3 ft. trees, parcel post. prepaid

.65

Price, all varieties:

PIUMS

Each

$\$ 0.80$

to $4 \mathrm{ft}$. trees, by express

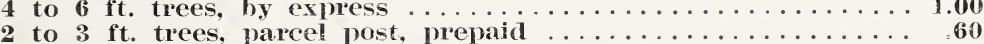

Price, all varieties:

CHERRIES

Each

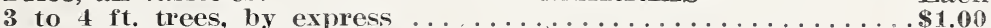

4 to 5 ft. trees, by expres

2 to 3 ft. trees, parcel post, prepaid

Price, all varieties:

QUINCES

Each

3 to 4 ft. trees, by express

$\ldots \ldots \ldots \ldots \ldots \ldots \ldots+\ldots \ldots$

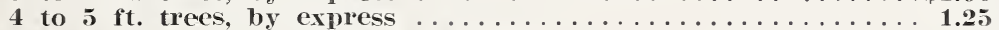

2 to 3 ft. trees, parcel post, prepaid

Price, all varieties:

PIEACHES

Each

3 to 4 ft. trees, by express

.$\$ 0.35$

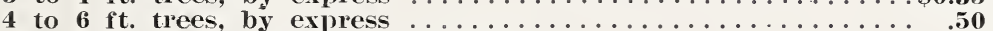

2 to $3 \mathrm{ft}$. trees, parcel post, prepaid

.30

$500 \quad 1000$

$\$ 35.00 \quad \$ 60.00$

30.00 50.00

$\begin{array}{rr}\mathbf{1 0} & \mathbf{1 0 0} \\ \mathbf{\$ 3 . 5 0} & \$ 30.00 \\ \mathbf{6 . 0 0} & \mathbf{5 0 . 0 0}\end{array}$

3.00

10

$\$ 7.00$

9.00

5.50

10

$\$ 7.00$

9.00

5.00

10

10.00

6.50

10

10.00

6.50

10
$\$ 3.00$

3.00
4.00

2.50
100

$\$ 60.00$

80.00

100

$\$ 60.00$

80.00

100

$\$ 75.00$

90.00

100

$\$ 75.00$

90.00

100

$\$ 25.00$

35.00 


\section{Lake Shore Fruit Trees}

\section{Apples}

The rarieties listed below are those which have been thoroughly testea and proved the best for this section of the country.

SUMMER VARIETIES

RED ASTRACHAN. The earliest variety: large; red; slightly acid; an old favorite.

YELLOW TRANSPARENT. Rapid grower: bears young; flesh white; very tender and juicy.

DICHESS OF OLDENBURG. The best market, best cooker, and very productive. Yellow, streaked red; juicy and rich.

\section{AUTUMN VARIETIES}

WEALTHY. Hardy, vigorous very productive. Good for eating or cooking.

MAIDEN BLCSH. Large; yellow with red cheek.

RAMBO. Medium yellow; streaked red.

\section{WINTER VARIETIES}

GRIMES GOLIDE. Large; golden yellow; juicy and tender; vigorous and productive.

WOLE RIVER. Largest of all; very hardy.

BALDIII. Large; bright red; rich in flavor and a good keeper.

DELICIOCS. Large: dark red; flesh fine grained; a good shipper and bears regularly

JONATH.N. Medium size; deep red; good keeper; very attractive.

NORTHERN SPY. Very large; striped; flesh yellow and tender. A reliable variety.

WINTER BINANA. A beautiful, golden yellow apple with a banana flavor.

HYSLOP CRAB. Large; deep crimson; very beautiful.

\section{GRENNING \\ ROME BEAUTY \\ TALMLIN SWEET \\ WINESAP \\ YORK IMPERIAL \\ McINTOSH RED}

OTHER VARIETIES

\section{Peaches}

ROCHESTER. Earliest; yellow with red cheek.

ELBERTA. Very large; yellow, red cheek; hardy; a heavy bearer and good shipper. Best market variety.

KALAMAZOO. Medium yellow; fine grain; heavy bearer.

ENGEL'S MAMMOTH. Large yellow; nearly round; a good yielder.

J. H. HALE. Very large and firm; yellow; very productive.

\section{Quince}

ORANGE. Largest and most productive.

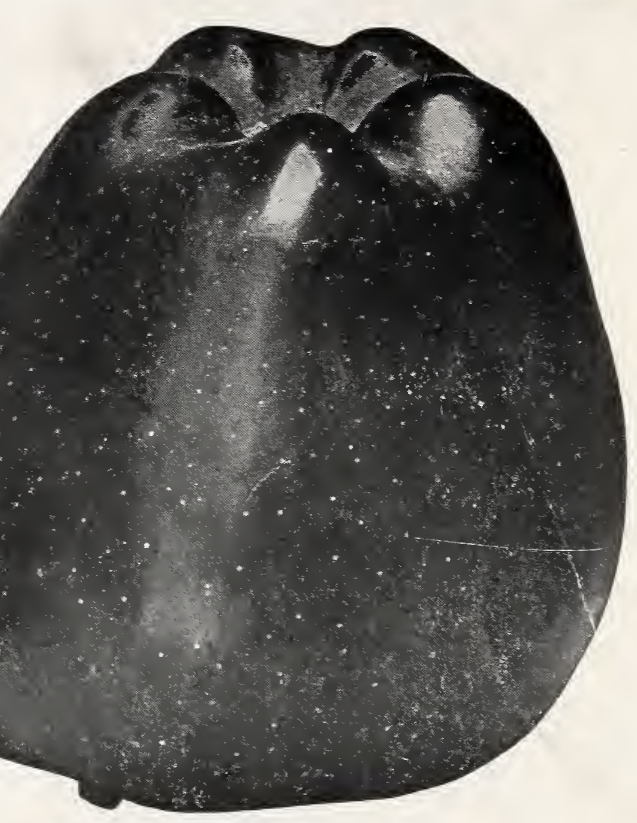

Delicious Apple.

\section{Cherries}

EARLY RICHMOND (Sour). A sure cropper; bears early; fruit medium dark red. MONTMORENCY (Sour). Large; productive; deep red; juicy and rich; trees large growers.

GOV. WOOD (Sweet). Large; red; rich and delicious; very productive.

TARTARI. (Sweet). Black; very large and juicy.

\section{Pears}

BARTLETT. Early: large; yellow; juicy; fine grain; richest flavor; productive.

CLAPP'S FIVORITE. Very large; yellow tinted red; fine flavor; bears young.

SECKEL (Sugar Pear). Yellowish-brown with red cheek; very rich; small; fine for pickling.

KIEFFER. A good winter pear; extensively grown; large: deep yellow: a good keeper; perfectly hardy and free from disease.

\section{Plums}

ABUNDANCE. Hardy and productive; flesh yellow, good flavor and quality.

BURB.NK. Large; flesh yellow; skin deep red; tree hardy; exceedingly productive: bears young.

DAMSON. Medium dark purple; very productive; best for preserving, etc.

\section{Apricots}

ROYAL. Large; beautiful; productive; home use or market. 